\title{
ŻAŁOBA, ROZPACZ, ŚMIERĆ - ANALIZA KAZUSU. PRÓBA DOOKREŚLENIA SPECYFIKI PRACY DORADCZO-FILOZOFICZNEJ
}

\begin{abstract}
Streszczenie. Przedstawione rozważania prezentują próbę namysłu nad zasadami i metodyką pracy doradczo-filozoficznej z uwzględnieniem kazusu z własnej praktyki, dotyczącego przeżywania żałoby. Podejście filozoficzne zostanie ukazane w porównaniu do pomocy psychologicznej, na przykładzie terapii krótkoterminowej, zorientowanej na rozwiązania, oraz coachingu jako formy pracy nakierowanej na rozwój. Głównym celem artykułu jest ukazanie specyficznych potrzeb, na które może odpowiedzieć doradztwo filozoficzne. W przekonaniu, że wnosi ono wartości, które nie są oferowane, przynajmniej w tym samym stopniu, w innych omawianych tu formach pracy. Prowadzona refleksja koncentruje się pośrednio również na kwestii wymagań kompetencyjnych, koniecznych w doradztwie filozoficznym.
\end{abstract}

Słowa kluczowe: doradztwo filozoficzne, psychoterapia, coaching, egzystencjalizm, dialogika

1. Wstęp. 2. Praca z osobami przeżywającymi rozpacz po stracie w poradnictwie krótkoterminowym a doradztwo filozoficzne. 3. Kazus z praktyki doradczo-filozoficznej: praca z osobą w rozpaczy po stracie. 4. Neutralność doradcy wobec wyborów światopoglądowych a zaangażowanie w relację. 5. Kontrakt procesu a cele sponsora. 6 . Dylemat na poziomie relacji. Coaching a doradztwo filozoficzne. 7. Podsumowanie.

\section{WSTĘP}

Mnogość propozycji terapeutycznych, poradnictwa pedagogiczno-psychologicznego oraz rozwój coachingu może rodzić pytanie o sens i potrzebę uzupełniania tak bogatej oferty o nową formę, jaką są usługi doradczo-filozoficzne. Doradztwo tego typu jest wciąż słabo rozwinięte i mało znane w Polsce. Można przywołać argument, który wręcz podważa sensowność tego typu praktyki. Wszakże bogata, 
antyczna tradycja ${ }^{1}$, a również późniejszy namysł filozoficzny zostały twórczo wykorzystane przez różne nurty psychoterapeutyczne. Zatem, ponieważ inspiracje filozofią obecne są w psychoterapii, to wnosić stąd można, że domena praktycznego oddziaływania na człowieka nie należy już wprost do samej filozofii. W wyniku oddzielania się nauk od filozofii, w wyniku postępującej ich autonomizacji i specjalizacji, wyłoniły się też pewne formy - ukonstytuowane na takich dyscyplinach, jak psychologia, pedagogika czy socjologia - pracy z człowiekiem. Zaś sama filozofia, poczynając od doby XIX-wiecznego pozytywizmu i scjentyzmu, została zmarginalizowana, lub „nabawiała się” kompleksu naukowej ścisłości, który uczynił zeń hermetyczną, akademicką dziedzinę. Takie rozumienie relacji filozofii do nauk pozwala wątpić w to, by mogła ona jeszcze przysłużyć się w praktyce. Rodzi pytanie, po co wracać do filozofii w postaci doradztwa, poradnictwa, czy też jakiejś formy psychoterapii? Co filozofia może jeszcze zaoferować współcześnie?

Rozumowanie takie, jak przedstawione powyżej, opiera się na dość uproszczonym wyobrażeniu o filozofii, a ponadto zakłada, co jest dość dyskusyjne, że istnieje ścisły związek np. między naukową psychologią a praktyką psychoterapeutyczną. Tymczasem liczne nawiązania do filozofii, w tym także do jej współczesnych nurtów i postaci, łącznie z postmodernizmem, obecne w różnych, często odległych od siebie nurtach psychoterapii, odczytać można jako wyraz użyteczności filozofii dla praktyków zajmujących się pracą z człowiekiem. Wiąże się to również z nowym typem poszukiwań, jak podkreśla bowiem Colin Feltham, obecnie „terapia stała się dla wielu ludzi sposobem poszukiwania egzystencjalnego, duchowego i metafizycznego sensu oraz doświadczeń transcendentnych"2. Z kolei kontynuator dziedzictwa

1 Zob. T. Femiak, Terapia filozoficzna, czyli doradztwo filozoficzne w działaniu, w: Psychoterapia. Pogranicza, red. L. Grzesiuk, H. Suszek, Warszawa 2012, 461-488.

2 C. Feltham, Rodzaje celów, w: Psychoterapia i poradnictwo, red. C. Feltham, I. Horton, t.1, tłum. z ang., J. Bartosik, S. Pykiel, E. Zaremba, P. Bucki, Sopot 2013, 58-59. 
Viktora Emila Frankla i twórca Osobowej Analizy Egzystencjalnej - Afried Längle - zauważa, że oprócz traumatycznych przeżyć, psychoterapia dotyczyć ma rozeznania możliwości rozwoju, a także być odpowiedzią na pytanie po co?, gdyż „brak im [ludziom - A.W.] celu w życiu i ów brak czyni ich chorymi. Wszystko staje się puste, wszystko jest dla nich bezsensowne"3. Dodaje też, że pewne formy zależności, fanatyzmu i egzystencjalnej pustki można ujmować jako problemy związane ze znaczeniem, sensem. „Ludzie cierpią z powodu braku spójności w relacji do wartości wyższych, dającej zrozumienie dla własnych działań i bycia w świecie"4.

Nietrudno zauważyć, jak mocno obecne są tu nawiązania do kwestii przynależących tematycznie do obszaru dociekań filozoficznych. Przywołane wypowiedzi wskazują na aktualność zapotrzebowania na wykorzystanie tematów i pytań filozoficznych w poradnictwie psychologicznym. Otwiera to także przestrzeń dla autonomicznych działań doradców filozoficznych, którzy mogą, na takie potrzeby odpowiedzieć. $\mathrm{Na}$ przykład pracując $\mathrm{z}$ osobami przeżywającymi kryzys duchowy, czy dylematy moralne lub światopoglądowe, stojącymi przed podjęciem ważnych życiowych decyzji, poszukującymi zrozumienia samych siebie $\mathrm{w}$ świecie nasyconym wieloma, konkurującymi ze sobą wartościami.

Celem artykułu będzie głównie przedstawienie kazusu z własnej praktyki, ale stanie się to również okazją do podjęcia rozważań dotyczących takich kwestii, jak:

1. porównawcze odniesienie doradztwa filozoficznego do poradnictwa krótkoterminowego, zorientowanego na rozwiązania w obszarze pracy z żałobą,

3 A. Längle, Analiza egzystencjalna - poszukiwanie zgody na życie, Psychoterapia (2003)2(125), 33-46.

4 A. Längle, Rozmowa terapeutyczna jako droga odkrywania siebie samego. „Drogowskazy” do wolności, Psychoterapia (2003)1(124), 41-54. 
2. ujawnienie wybranych podobieństw i różnic w zakresie metodyki pracy oraz sytuacji klientów w coachingu i w doradztwie filozoficznym,

3. refleksja nad dookreśleniem reguł pracy i wymagań kompetencyjnych koniecznych do pełnienia roli doradcy filozoficznego w kontekście pewnych problemów i dylematów etycznych.

\section{PRACA Z OSOBAMI PRZEŻYWAJĄCYMI ROZPACZ PO STRACIE W PORADNICTWIE KRÓTKOTERMINOWYM} A DORADZTWO FILOZOFICZNE

Przytaczany przykład podejścia psychoterapeutycznego jest tylko jednym z wielu możliwych sposobów pracy z żałobą. Poniższa analiza nie jest też próbą jego dyskredytacji przez ujawnienie sprzeczności. Postaram się jednak pokazać, że pomimo deklarowanego dystansu do kultury współczesnej, z typową dla niej marginalizacją śmierci, $\mathrm{w}$ wybranym podejściu zaznacza się również pewien rodzaj niezgody na długotrwałe przeżywanie straty. Ilustruje to prawdopodobnie dominujący rys pomocy psychoterapeutycznej w tym zakresie, ujawniający się w czynieniu człowieka na powrót użytecznym społecznie. Co niestety może odbywać się kosztem konfrontacji z istotnymi dla samopoznania i określenia własnej postawy, trudnymi doświadczeniami egzystencjalnymi.

Judith Milner i Paric O’Byrne piszą, że „ludzie zrozpaczeni często przychodzą na terapię skierowani przez innych"5 - autorzy podkreślają jednak, że sami nie uważają rozpaczy jako takiej za problem, gdyż jest ona w pełni naturalną reakcją na utratę bliskiej osoby. Pokazując metodykę własnej pracy w sytuacji rozpaczy, dodają, że „W odpowiednim momencie (po tym jak [klienci-A.W.] opowiedza już swoją historię i zwykle nieco popłaczą) pytamy klientów, czego

5 J. Milner, P. O’Byrne, Poradnictwo krótkoterminowe: narracje i rozwiązania, red. J. Camping, tłum. z ang. M. Trojański, Poznań 2007, 189. 
osoby, które ich skierowały, spodziewają się po terapii. Pytamy też, czy zgadzają się z nami i jaki jest ich racjonalny cel, nad którym będziemy pracować"6. Ujawniają się przy okazji dwa istotne momenty; pierwszy to poszukiwanie racjonalnego celu, a drugi to zdystansowanie się wobec traktowania rozpaczy jako stanu patologicznego. Ta ostatnia kwestia staje się okazją do krytyki kultury zachodniej, $z$ uwagi na zanik naturalnych form wsparcia, jakich dostarczały tradycyjne rytuały związane ze śmiercią i żałobą, w miejsce których pojawia się skrępowanie wobec uzewnętrzniania rozpaczy ${ }^{7}$. Przemiana, o której tu mowa, jest związana między innymi z procesami postępującej sekularyzacji, atomizacji życia, zaniku dawnych wzorców aksjonormatywnych oraz technicyzacji, które otwierają pole również dla pracy doradczo-filozoficznej, w odpowiedzi na zagubienie człowieka. Naruszone zostały dawne wzorce związane z postrzeganiem cyklu życia, w którym starość, śmierć traktowane były jako elementy naturalne, a nie jako na razie jeszcze nie przezwyciężone bolączki. Współczesna kultura zdaje się umacniać taki właśnie obraz, jakby śmierć i przemijanie w przyszłości należało definitywnie pokonać.

W terapii krótkoterminowej, pomimo wstępnie deklarowanego akceptującego stosunku do rozpaczy po stracie, ujawnia się - typowy dla dyskursu psychoterapeutycznego - problem normalizacji tego stanu. Pojawia się pytanie, jak długo rozpacz trwać powinna, jaki jej przebieg jest normalny, od kiedy zaczyna się rozpacz patologiczna? Ogólna reguła, głosząca, że rozpacz ,jest tak długo zdrowa, jak długo przechodzi w tempie i w sposób określony przez ogarniętych nią ludzi"8, akceptująca indywidualny sposób jej doświadczania bez narzucania sztywnych ram czasowych, uzupełniona zostaje sugestią, że co prawda „zwykła rozpacz nie powinna być uważana za problem, staje się jednak nim, gdy jest długotrwała i ciężka”. A to

6 Tamże.

7 Zob. tamże, 190.

8 Tamże. 
ostanie twierdzenie zdaje się po części zaprzeczać przyzwoleniu na jej indywidualny przebieg. Pojawia się tu na jednym biegunie „zwykła rozpacz”, która nie jest problemem, a na drugim rozpacz „długotrwała i ciężka”, która, przynajmniej implicite, jest traktowana jako problem, jako zaburzenie normalnego funkcjonowania. Pomimo zatem wstępnych deklaracji, że terapia krótkoterminowa, to praca na zasobach klienta, która szczególnie w podejściu zorientowanym na rozwiązania, opiera się na założeniu - podobnie jak w coachingu że to klienci są ekspertami od własnego życia ${ }^{9}$, uwidacznia się tu przynajmniej w sytuacji rozpaczy - ekspercka przewaga terapeuty, który wie, co przekracza już adaptacyjną miarę normalności, a ta określana jest zunifikowanymi kryteriami diagnostycznymi. Jest to w mojej opinii - prawdopodobnie wynik przyjęcia założeń, że w tej postaci psychoterapii chodzi nie tyle o zrozumienie czy wyjaśnienie, lecz o rozwiązanie problemów ${ }^{10}$, przy jednoczesnym nastawieniu na tworzenie własnej przyszłości klienta „bez problemu”11. Właśnie te przekonania przekładają się na sposób pracy z osobami w rozpaczy po stracie, który podany jest regule zadawania pytań ukierunkowanych na przyszłość, w tym pracę pytaniem o cud ${ }^{12}$, czy też skalowanie najmniejszych nawet oznak poprawy w celu umocnienia wiary klienta we własne siły i możliwość innego doświadczania życia. Jest ot praca bazująca na modelu $\mathrm{O}$ (outcome - rezultat), S (skalowanie), K (know-how), A (action), R (rewiew) ${ }^{13}$. Jej zadaniem zaś jest zatem nie tylko budowanie nadziei na przyszłość, po tym ,jak [klienci-A.W.] opowiedzą już swoją historię i zwykle nieco popłaczą", ale również uczenie dostrzegania tych momentów, w których jest lepiej, by wykorzystać je bardziej świadomie w tworzeniu strategii aktualnego i przyszłego działania. Podejście krótkoterminowe nie pozwala tym

9 Zob. tamże, 10-13.

10 Zob. tamże, 15-16.

11 Zob. tamże, 18.

12 Zob. tamże, 190-191.

13 Zob. tamże, 192. 
samym klientom zbyt długo trwać w dezintegracyjnym doświadczeniu pustki po stracie.

Doradztwo filozoficzne może w kwestii pracy z żałobą, rozpaczą, śmiercią, oferować coś więcej niż tylko zorientowanie na lepszą przyszłość przy akceptacji dla wyrażenia emocji przez podopiecznego. Chociaż i taki charakter mogłoby przybrać, gdyby życzeniem klienta stało się odzyskanie utraconego sensu na skutek śmierci kogoś bliskiego. Zanim jednak dojdzie w człowieku do głosu potrzeba przywrócenia hedonicznej jakości życia, często najpierw pojawiają się istotne pytania, identyfikowane jako filozoficzne. Rodzą one potrzebę - by posłużyć się określeniem Karla Jaspera - rozjaśnienia egzystencji w obliczu sytuacji granicznych ${ }^{14}$. Towarzyszenie w takim momencie, stworzenie szansy jego zrozumienia, otwarcia się na metafizyczne residuum życia jest cennym wkładem, który może wnieść doradca filozoficzny. „Magna quaestio (...) zaczyna się od słowa Dlaczego?, które natychmiast człowiekowi przychodzi na myśl w chwilach zaskoczenia, rozczarowania, zdziwienia lub rozpaczy (...) w sytuacjach granicznych rozbijających integralność ludzkiego bytu" 15 . Jest to czas budzenia się w człowieku potrzeby samookreślenia, która często jest ważniejsza niż cele adaptacyjne. Przedstawione tu wartościowanie uznać można co prawda za problematyczne. Doradztwo filozoficzne może tworzyć pewną przeciwwagę dla postrzegania wartości człowieka i jego doświadczeń, w kategoriach gotowości do sprawnego pełnienia ról społecznych. Apeluje ono raczej do troski o samego siebie i samopoznania.

14 Søren Kierkegaard rozpoznaje, że skrajne stany egzystencjalne odsłaniają to, co znajduje się w utajonej formie w codziennym doświadczeniu człowieka, pisze: „gdy tylko rozpacz się objawia, okazuje się, że człowiek już przedtem był zrozpaczony”. S. Kierkegaard, Choroba na śmierć, tłum. z duń. J. Iwaszkiewicz, Warszawa 1995, 25. Podążając za tą myślą, uznać można zatem, że sytuacje te dają szczególną okazję do wglądu w siebie.

15 Z. Pucko, Zrozumieć utratę. Magna quaestio w obliczu żałoby, Kraków 2011, 7. 


\section{KAZUS Z PRAKTYKI DORADCZO-FILOZOFICZNEJ: PRACA Z OSOBA W ROZPACZY PO STRACIE}

Miałam okazję pracować z kobietą w wieku emerytalnym, nazwę ją Krystyną i zmienię kilka faktów z jej biografii, aby zapewnić ochronę poufności. O rozmowę z Krystyną zostałam poproszona przez jej dorosłe już dzieci, które uskarżały się na jej „zbyt długo trwającą żałobę”. Krystyna pełniła w rodzinie rolę babci-opiekunki swoich kilkuletnich wnuków. Kobieta przeżywała od około czterech miesięcy żałobę po śmierci matki, którą opiekowała się podczas trwającej kilka miesięcy choroby. Zakończyła się ona, co ma znaczenie dla opisywanej sytuacji, zgonem w szpitalu. Bolesne doświadczenie żałoby wiązało się tu - jak pokazała rozmowa $-z$ poczuciem winy wobec matki. W najbardziej zewnętrznej warstwie dotyczyło to faktu, że Krystyna nie była obecna przy szpitalnym łóżku w momencie śmierci matki. Wspomnienie to wzbudzało łzy i poczucie nieodwracalnej straty związanej z niemożliwością odwrócenia biegu wydarzeń. W narracji Krystyny często powtarzały się zwroty „a gdybym nie wyszła ze szpitala, tylko została z mamą na noc...” lub „nie mogę sobie tego wybaczyć, że nie było mnie wtedy". Ujawniało się tu głębokie egzystencjalne doświadczenie uwikłania jednostki w koleje nieodwracalnego losu, niemożność przewidzenia i poddania kontroli biegu wydarzeń, pomimo poczucia wolności dokonywanych wyborów. Moje interwencje na tym etapie ograniczały się do empatycznego wysłuchiwania opowieści, ale również naświetlania kwestii związanych z ograniczonym wpływem człowieka na bieg wydarzeń.

Poczucie winy mojej rozmówczyni było dodatkowo nabudowane na tym, że jej matka trafiła do szpitala na skutek wypadku. Krystyna interpretowała to jako nieszczęśliwy rezultat swojego niedopatrzenia, żałowała, że nie przewidziała wszystkich okoliczności, nie uprzedziła zdarzeń. Dla słuchacza jasne było jednak to, że były to rzeczy, na które nie mogła mieć wpływu, a sam wypadek nie nastąpił w wyniku jej zaniedbania. Również wątki osnute wokół tematu wypadku Krystyna 
wielokrotnie powtarzała. Odnieść można było wrażenie, jakby przekonywała samą siebie, czasem zaś jakby przez powtarzanie słów i zdań chciała cofnąć sytuację. Pojawiało się też pytanie: „dlaczego nie powstrzymałam mamy?”. Moje działanie nadal sprowadzało się do wysłuchania opowieści, obecności w chwilach wybuchów płaczu. Starałam się wykorzystać momenty, w których emocje przygasały, by coraz bardziej angażować Krystynę w rozmowę na temat tego, co faktycznie było od niej zależne, a co zupełnie niezależne. A przez podstawienie w tę historię ,abstrakcyjnego człowieka” zmierzałam do uzyskania jej wniosków na temat wpływu na omawianą sytuację.

Uderzające w tych rozmowach było jednak to, że Krystynę cechowało poczucie wszechmocy w relacji z matką, z którym w parze szło poczucie odpowiedzialności za wszystkie zaistniałe zdarzenia. Spróbowałam nawiązać w rozmowie do wyników badań dotyczących przeżywalności po wypadkach i urazach wśród osób starszych z chorobami przewlekłymi. Tego typu komentarze zdawały się zupełnie nie przemawiać do rozmówczyni. Najwyraźniej myślenie z poziomu „człowieka w ogóle” lub prawidłowości statystycznych nie pasowało do jej na wskroś osobistego zmagania z bolesną koniecznością. Uznałam jednak, że być może warto podkreślać komunikaty typu: „to nie było od Pani zależne, nawet gdyby ostrzegła Pani matkę, mogłoby to i tak nic nie dać, nie mogła Pani kontrolować wszystkiego, żaden człowiek tego nie potrafi”, z nadzieją, że być może po jakimś czasie włączy jednak te słowa w swój wewnętrzny dialog i staną się one częścią jej prywatnej opowieści o roli, jaką odegrała w tej sytuacji. Ujawnia się tu intencja towarzysząca mojej pracy, a tym samym rys dyrektywny, założyłam bowiem, że osobiste doświadczenie warto integrować z obiektywnymi uwarunkowaniami egzystencji - skończonością człowieka, ograniczonym wpływem na rzeczywistość, który nie przekreśla odpowiedzialności za podejmowane wybory, ale może niwelować poczucie winy związane z przypisywaniem sobie zbyt dużego, bo wykraczającego poza ludzkie możliwości sprawstwa. Zaś doświadczanie odpowiedzialności za cały bieg zdarzeń 
w świecie nie prowadzi do rozjaśnienia egzystencji w konfrontacji $\mathrm{z}$ winą ${ }^{16}$, co mogłoby być ujmowane w kategoriach patologicznego poczucia winy ${ }^{17}$.

Kolejna rozmowa z Krystyną ujawniła nowe treści, choć powtarzały się jeszcze dawne motywy. Na jaw wyszło poczucie osamotnienia w dosyć dużej rodzinie. Towarzyszyło ono jej przez cały okres żałoby. Wynikało to z dwóch przyczyn, choć nie zostało to nazwane w ten sposób i wypłynęło raczej między słowami. Po pierwsze, jej mąż i dzieci nie przeżywali odejścia matki Krystyny tak mocno wrócili do swoich spraw, do życia, ze zdziwieniem i pewną dozą niechęci spoglądali na jej rozpacz. Drażniło ją to, że zachęcają ją do jedzenia, kiedy ona nie ma apetytu, lub kwitują jej smutek słowami: „no przestań się już zamartwiać”. Miała poczucie, że się oddalili, a dodatkowo, postrzegają jej stan jako dziwny i niepożądany. Sama Krystyna nie uskarżała się jednak na stan żałoby, dla niej poddanie się rozpaczy było zupełnie naturalne i nie chciała $z$ tego wychodzić, by dopasować się do życzeń otoczenia. Doświadczała tego - w moim odczuciu - jako czegoś świętego, choć było to dla niej raczej mysterium tremendum, zupełnie jakby poddała się działaniu jakiejś wyższej siły, która owładnęła nią całkowicie, której nie mogła się przeciwstawić, ale też nie chciała. Było to dla niej doświadczenie dezintegracyjne, przed którym jednak nie chciała uciekać i wracać do poprzedniego sposobu funkcjonowania ${ }^{18}$. Nasuwało się porównanie z pacjentami

16 Zob. M. Żelazny, Filozofia i psychologia egzystencjalna, Toruń 2011, 277-278.

17 Piotr Olaf Żylicz, analizując poczucie winy w ujęciu psychologicznym, zwraca uwagę, że nie ma jednolitego sposobu rozumienia poczucia winy i roli, jaką ma pełnić w życiu człowieka zdrowego. Zasadniczo rozróżnia się jednak zdrowe i patologiczne poczucie winy. Różne podejścia psychoterapeutyczne dysponują odmiennymi sposobami rozumienia tej kategorii i jej znaczenia w życiu jednostki, pochodnymi od założeń na temat natury ludzkiej. P.O. Żylicz, Praca psychoterapeutyczna z osobami doświadczającymi poczucia winy, w: Psychoterapia. Praktyka, red. L. Grzesiuk, Warszawa 2006, 517.

18 Koncepcja dezintegracji pozytywnej Kazimierza Dąbrowskiego ukazuje, że trudne doświadczenia, a za takie można uznać przeżywanie śmierci bliskiej osoby, są okazją do integracji osobowości na wyższym poziomie niż wyjściowy, co ujawnia się np. w pogłębieniu empatii. 
Frankla, którzy szukali sensu cierpienia, a nie środków zewnętrznie uśmierzających ich aktualny $\operatorname{stan}^{19}$.

Zgoda na poddanie się $\mathrm{i}$ trwanie $\mathrm{w}$ stanie przeżywanym przez Krystynę mogłaby być oczywiście interpretowana jako brak woli walki lub odmienny (resp. niewłaściwy) sposób doświadczania, który należałoby zmienić, aby zniwelować cierpienie i poprawić jej osobiste oraz społeczne funkcjonowanie. Podejście takie jest niewątpliwie redukcjonistyczne ${ }^{20}$, a ponadto nosi znamiona strategii eskapistycznej ${ }^{21}$, którą narzuca się pacjentowi/klientowi, bez uświadomienia znaczenia przeżywanej sytuacji. Co oznacza, że nie jest on traktowany w pełni podmiotowo na skutek arbitralnie przyjętego założenia, że cierpienie jest złem, które zagraża jakości życia. Tak jakby jakość życia ujmowana była jedynie na osi przyjemność - ból, a nie w odniesieniu do odczucia głębi i sensu doświadczenia. Podejście to nie uwzględnia istotnego zjawiska obecnego w stanie żałoby, czyli samego otwarcia się na przeżywanie aktualnego stanu, wejście weń i konfrontowanie się z przemijaniem, skończonością i losem. Praca z Krystyną ukazała

Działania zmierzające do przywrócenia optymalnego funkcjonowania i niwelacji cierpienia mogą być zatem interpretowane jako zakłócające rozwój jednostki. Zob. K. Dąbrowski, Elementy filozofii rozwoju, Warszawa 1989, 50-52. Na gruncie badań empirycznych nad traumą ujawniają się podobne wnioski. „Osoby poddane różnego rodzaju traumatycznym zdarzeniom oprócz symptomów posttraumatycznego stresu doświadczają również pozytywnych zmian w życiu będących rezultatem przeżywanej traumy (...) Możliwe jest mianowicie odnalezienie pozytywnego aspektu trudnego zdarzenia poprzez uświadomienie sobie znaczenia sensu w procesie życia”. K. Popielski, P. Mamcarz, Trauma egzystencjalna a wartości, Warszawa 2015, 14.

19 Dla Frankla stało się to źródłem przekonania, że „(...) nie wolno nam uwalniać człowieka od cierpień za cenę poświęcenia jego osoby”. V.E. Frankl, Homo patiens, tłum. z ang. R. Czarnecki, J. Morawski, Warszawa 1984, 16. Według Frankla doświadczenie cierpienia odgrywa bardzo ważną rolę w duchowym rozwoju człowieka; zob. M. Wójtowicz, Doświadczenie lęku egzystencjalnego jako sytuacja wyboru, Katowice 2005, 89.

20 Pod pojęciem redukcjonizmu rozumiem tu sprowadzenie wartości człowieka do jego społecznej użyteczności, przydatności do wykonywania zadań życiowych.

21 Przywracanie stanu sprzed żałoby można interpretować jako ucieczkę przed doświadczaniem trudnych sytuacji życiowych, w tym przypadku żałoby po stracie. 
mi, że tę właśnie możliwość powinno dać doradztwo filozoficzne, w którym przez towarzyszenie w przeżywaniu otwiera się przestrzeń dla zadawania głębokich pytań, zbierania wniosków z doświadczeń, zachęcania do przedstawienia ich interpretacji i ukazywania (również w oparciu o wybrane koncepcje filozoficzne) wagi tego typu przeżyć dla formowania się dojrzałego, pełnego bycia i rozumienia ludzkiej kondycji. Również to podejście opiera się na pewnych założeniach, które wprowadzają określone wartościowania, ale wydaje się słuszniejsze chociażby przez fakt, że apeluje $\mathrm{w}$ większym stopniu do autonomii osoby, z którą się pracuje, a docelowo ją wzmacnia. Dodatkowo szansa na doświadczenie osobistego cierpienia jako udziału w powszechnej kondycji ludzkiej ma walor działania normalizującego $^{22}$, w odróżnieniu od podejścia, w którym proponuje się pracę zorientowaną na przywrócenie stanu sprzed żałoby.

Wracając do pracy z Krystyną, warto podkreślić, że przywołana już prośba skierowana ze strony jej dzieci, która rozpoczęła naszą współpracę, nabiera w tym kontekście symptomatycznego charakteru. Była jak głos społeczeństwa, które woła: Wracaj do nas! Bądz taka, jak dawniej! Nie podzielałam jednak zdania jej bliskich, toteż postanowiłam, że w żadnym momencie naszej rozmowy nie odniosę się do kwestii jej ról rodzinnych, a zatem również rzekomych obowiązków, czy mniej lub bardziej wyraźnie artykułowanych oczekiwań otoczenia, starając się podążać za treściami, które sama wnosiła do naszej relacji. $Z$ czasem pojawił się nowy wątek, Krystyna wskazała też drugie źródło swego bólu - rozmowy z bratem o śmierci matki. $\mathrm{Z}$ nim rozmawiała najczęściej, głównie telefonicznie, lecz wspólne przeżywanie miało dość osobliwy charakter. Otóż brat, jako ateista, podważał wiarę Krystyny w życie pozagrobowe, w Boga, wskazując na argumenty materialistyczne, tak jakby były to obiektywne prawdy nauki i każdy człowiek powinien je przyjąć. Brat Krystyny,

22 Ukazuje zatem, że cierpienie też jest jedną ze składowych życia, nie zaś niepożądanym stanem, który należałoby wyeliminować, w celu przywrócenia „normalnego” funkcjonowania. 
jak można przypuszczać, odreagowywał własny ból, manifestując swoje pogodzenie ze śmiercią, w sposób sugerujący potrzebę zaznaczenia wyższości nad wierzącą, czyli w jego ocenie naiwną siostrą.

Sytuacja ta stała się paradoksalnie punktem zwrotnym relacji z Krystyną, po raz pierwszy bowiem w czasie naszych rozmów skierowała do mnie prośbę, by powiedzieć jej, jak jest naprawdę z życiem pozagrobowym. Miałam wykazać, że brat się myli. Jest to swoją drogą przykładem oczekiwań adresowanych do filozofa, który ma wystąpić z pozycji rozstrzygającego autorytetu i w domyśle potwierdzić stanowisko swego rozmówcy. W procesie doradczo-filozoficznym, podobnie, jak w procesie coachingowym czy terapeutycznym warto odnieść tego typu zdarzenia do aktualnej relacji między stronami, przywołać wzajemne rozumienie ról i sens adresowanych w ten sposób oczekiwań oraz poddać refleksji to, czego strona prosząca oczekuje.

W sensie treściowym, w tym konkretnym procesie pojawia się jeszcze jeden wymiar - odpowiedzialność za zachwianie wiary rozmówczyni. Zdając sobie sprawę z delikatności sytuacji postanowiłam, że zachowam bezstronność, i nie będę odbierać Krystynie tego, co stanowi jej pocieszenie - wiary. Pokazałam jednak, że poglądy brata są też pewnym typem wierzeń światopoglądowych, w przystępny sposób omówiłam wnioski wypływające z Kantowskiego podziału świata na sferę doświadczenia i rzecz samą w sobie oraz metafizyczne pytania, które pozostają bez odpowiedzi. Część tej pogadanki poświęcona była też kwestii możliwości pogodzenia stanowiska ewolucjonistycznego jej brata z kreacjonizmem, który wyznawała Krystyna. Uznałam, że umacnianie jej w wierze, przez dobór argumentów i koncepcji stosownie do wyartykułowanych oczekiwań, byłoby niewłaściwe, naruszałoby bowiem istotną dla roli filozofa niezależność i unikanie opowiadania się za pewnym tylko typem poglądów. Mogło to bowiem również przynieść skutek odwrotny, gdyby bowiem utraciła wiarę, ja mogłabym w wyniku tego utracić wiarygodność, jako partner w dalszych rozmowach, który jedynie próbował ją pocieszyć. Pocieszenie - wbrew filozoficznej tradycji 
consolatio - nie powinno być głównym celem pracy w poradnictwie filozoficznym, przynajmniej takim, dla którego ważne są wartości związane $z$ podmiotowym traktowaniem rozmówcy.

Miałam poczucie, że przez wybór opisanego działania odwołałam się do jej dorosłej, racjonalnej strony, wskazując na ograniczoność naszej wiedzy, a pośrednio ludzkiej kondycji w ogóle. Nie oczekiwałam, że da jej to jakieś ukojenie, choć potencjalnie tak mogło być. Nie starałam się jej jednak również pozbawiać tego, w co wierzy i osłabiać optymizmu dającego nadzieję na kontakt $\mathrm{z}$ matką po śmierci. Moje komentarze nie dawały jej punktu oparcia, którego potrzebowała, nie dawały jej ugruntowania, ale wzywały raczej do podjęcia wyboru pomimo niedookreśloności sytuacji. Nasze kontakty skończyły się po tej rozmowie, po której Krystyna doznała wzmocnienia i pogodzenia z sytuacją, jak oceniła to z perspektywy upływu czasu.

Sposób postępowania opisany powyżej nie wynikał ze z góry przyjętej, ścisłej metodyki pracy. Ujawnia jednak założenia charakterystyczne dla szeroko pojętej tradycji egzystencjalnej oraz nawiązania do filozoficznej dialogiki. Istotne dla postępowania filozoficznego choć nie tylko, zważywszy na istniejące nurty psychoterapii egzystencjalnej - jest towarzyszenie w trudnych życiowych sytuacjach, jednak bez narzucania ich wykładni w kategoriach normy i patologii. Bez określania prawidłowej dynamiki i czasu przeżywania żałoby. Doświadczenie pracy z Krystyną nauczyło mnie, że podejście minimalistyczne, maksymalnie niedyrektywne, polegające na współtowarzyszeniu i dzieleniu się filozoficznymi treściami w odpowiedzi na zapytania rozmówcy, ma przewagę nad - widocznym w początkowym sposobie mojego postępowania - wprowadzaniu racjonalnych argumentów w intencji pomocowej. Nie sposób przesądzić, która $\mathrm{z}$ interwencji $\mathrm{w}$ procesie miała znaczenie decydujące dla jego przebiegu, jednak kluczowe wydaje się pozwalanie na rodzenie się swoistego rozumienia sytuacji u samego rozmówcy i zjego inicjatywy. 


\section{NEUTRALNOŚĆ DORADCY WOBEC WYBORÓW ŚWIATOPOGLĄDOWYCH A ZAANGAŻOWANIE W RELACJĘ}

W omówionym przykładzie wybrzmiewa element nieopowiadania się po którejś ze stron $\mathrm{w}$ sporze o charakterze światopoglądowym. Można więc zadać pytanie, czy w pracy doradczo-filozoficznej pozostać maksymalnie neutralnym, czy opowiadać się za konkretną opcją filozoficzną, a jeśli tak, to za jaką lub za jakimi teoriami; jak neutralność zrealizować w praktyce, która ex definitione opierać powinna się na poszerzeniu horyzontów myślowych klienta, co zakłada również konfrontowanie go $\mathrm{z}$ odmiennymi punktami widzenia. Proponuje najpierw rozważać to in concreto $\mathrm{w}$ odniesieniu do pracy z żałobą w pewnym podejściu psychoterapeutycznym, by przejść do rozważań ogólniejszych dotyczących doradztwa filozoficznego. „Żałoba jest (...) ściśle związana z przekonaniami religijnymi i egzystencjalnymi. Czy terapeuta powinien odpowiadać na religijnie ukierunkowane pytania (...)? To zależy - odpowiadają autorzy Terapii traumy - od indywidualnych preferencji (...) prawdopodobnie odpowiedzielibyśmy szczerze, choć w sposób najbardziej zgodny z poglądami dziecka i rodziców. (...) Terapia $z$ reguły nie powinna przeradzać się w filozoficzną, czy teologiczną debatę"23. Pomijając kwestie poboczne, z którymi można by polemizować ${ }^{24}$, istotne jest tu sprostanie dwóm warunkom - szczerości i byciu w zgodzie z poglądami klientów.

23 J.A. Cohen, A.P. Maunarino, E. Deblinger, Terapia traumy traumatycznej żałoby u dzieci i młodzieży, tłum. z ang. R. Andruszko, Kraków 2011, 177-178.

24 Pogląd, że terapia nie powinna przeradzać się w filozoficzną czy teologiczną debatę można zinterpretować na co najmniej dwa sposoby. Po pierwsze jako zdanie głoszące, że terapeuta nie chce wdawać się w spory o słuszności takich lub innych przekonań, lecz wyraża akceptację dla poglądów i wierzeń swego klienta, po drugie, jako dewaluację terapeutycznego oddziaływania rozważań filozoficznych, a z tym akurat trudno się zgodzić m.in. w świetle definicji filozofii, ukazującej ją jako ars moriendi. Ponadto także w kontekście rozpoznań poczynionych przez psychoterapeutów egzystencjalnych. Zob. I.D. Yalom, Patrząc w słońce. Jak przezwyciężyć grozę śmierci, tłum. z ang. A. Dudziak, Warszawa 2008, 12 i nast. 
Ten drugi warunek, jak można się domyślać, służy zapewnieniu jak największego bezpieczeństwa w relacji, zachowania wewnętrznego zasobu, którym jest wiara podopiecznego.

Warunek szczerości w relacji można potraktować jako cenną wskazówkę do aplikacji w pracy doradczo-filozoficznej, bowiem oczekiwanie autentyczności i otwartości ze strony klienta bez analogicznej postawy z drugiej strony podważa sens wzajemnego współbycia. Praca filozofa powinna się opierać nie tylko na merytorycznej znajomości systemów, szkół i problemów oraz zdolnościach ich przekładania na język powszechnie zrozumiały, ale wymaga również, a może przede wszystkim, wysokich kompetencji w zakresie komunikacji i budowania relacji. Przygotowanie w tym zakresie nie może opierać się wyłącznie na teoretycznym zgłębianiu np. zasad filozofii spotkania Martina Bubera, czy reguł prowadzenia dialogu sokratejskiego, które, co prawda były i nadal pozostają znaczącym źródłem inspiracji dla praktyków w dziedzinie budowania relacji z człowiekiem. Równie potrzebne wydaje się otwarcie na proces zwrotnej recepcji tego, jak na język praktyki przekuły to różne szkoły psychoterapeutyczne. W związku z tym postulować można wcielanie $\mathrm{w}$ doradztwie filozoficznym zwłaszcza umiejętności zastosowania rogeriańskich zasad relacji terapeutycznej ${ }^{25}$, których przyjęcie wydaje się konieczne nawet pomimo zastrzeżenia, że praca filozoficzna nie opiera się tak mocno na emocjach, jak relacja psychoterapeutyczna ${ }^{26}$.

25 Zob. T. Merry, K. Tudor, Poradnictwo i psychoterapia skoncentrowana na osobie, w: Psychoterapia i poradnictwo, red. C. Feltham, I. Horton, t.1, tłum. z ang. J. Bartosik, S. Pykiel, E. Zaremba, P. Bucki, Sopot 2013, 521-528. Odnośnie do wykładni tych reguł w egzystencjalnej pracy nad odnalezieniem sensu życia zob. również I.D. Yalom, Psychoterapia egzystencjalna, tłum. z ang. A. Tanalska-Dulęba, Warszawa 2008, 493.

26 Wydaje się, że ukończenie studiów filozoficznych nie daje odpowiedniego przygotowania, by móc pracować z drugim człowiekiem lub grupą. Można mówić w tym kontekście o różnych zagrożeniach. Zob. A. Zembrzuska, Powrót do filozofii? Rzecz o poradnictwie filozoficznym, w: Poradnictwo w kulturze indywidualizmu, red. E. Zierkiewicz, V. Drabik-Podgórna, Wrocław 2010, 117-118. Postulaty związane z rozwijaniem kompetencji związanych z budowaniem relacji opartej na zaangażowaniu i empatii udaje się zrealizować 
Pozostaje jednak kwestia jak ma się szczerość do drugiego warunku - zgodności z poglądami klienta, który w cytowanym fragmencie przedstawiony został na równi z tym pierwszym jako możliwy do spełnienia na zasadzie „i jedno, i drugie”. Wydaje się trudne do realizacji, a nawet nie wskazane w doradztwie filozoficznym. Zgodność z poglądami klienta to wszakże opowiedzenie się po stronie „filozofii życiowej" rozmówcy, co nie sprzyja budowaniu otwartości myślowej, ani świadomego wyboru. Jednak w pracy z żałobą interwencje typu zaznajamiania $\mathrm{z}$ różnymi koncepcjami filozoficznymi mogącymi godzić w światopogląd podopiecznego powinny być prowadzone niezwykle ostrożnie. Praktykowane w coachingu proszenie o zgodę na proponowane ćwiczenia lub eksperymenty myślowe wypływające $\mathrm{z}$ jak najdalej posuniętej niedyrektywności tego podejścia można włączyć w sposób prowadzenia sesji doradztwa filozoficznego. To klient może określać, czy dany sposób pracy jest akceptowalny dla niego, czy też nie, doradca zaś nie powinien narzucać metodyki prowadzenia sesji, oczywiście w ramach, na jakie praca filozoficzna pozwala.

Doradztwo filozoficzne nie powinno być prowadzone jako działalność sprowadzająca się do udzielania rad jak żyć, a już zwłaszcza, jak żyć godnie z pewną, i tylko jedną filozofią życia. Na taką rolę doradcy wskazuje również działalność zagranicznych prekursorów powrotu do filozofii jako terapii lub poradnictwa ${ }^{27}$. Co nie wyklucza, że można, a nawet powinno się (oczywiście w sposób adekwatny do sytuacji i podejmowanego tematu sesji) prezentować różne filozofie

przez umieszczenie w programie studiów przygotowujących do prowadzenia poradnictwa filozoficznego znacznego udziału przedmiotów psychologicznych, treningu interpersonalnego oraz zajęć z coachingu. Po raz pierwszy w Polsce na Uniwersytecie Śląskim w Katowicach wprowadzono to na kierunku Doradztwo filozoficzne i coaching.

27 Zob. J. Mills, Philosophical Counseling as Psychotherapy: An Eclectic Approach, International Journal of Philosophical Practice 1(2008), 1-28. Analizę założeń licznych praktyków w tym zakresie przedstawia również A. Zembrzuska, dz. cyt., 110-111. 
i wspólnie z klientem badać zawarte w nich wskazówki praktyczne 28 . Chociaż sam człon 'do-radztwo' w nazwie 'doradztwo filozoficzne' może sugerować, że świadczący taką usługę występuje w funkcji dawcy rad, to intencja ta zostaje zrównoważona dzięki temu, co tkwi w jego dookreśleniu 'filozoficzne'. Filozofia cechująca się wielością stanowisk, mnogością wypracowanych metod, odmiennością w pojmowaniu własnych zadań, kształtująca się historycznie w krytycznym dialogu z własnymi ustaleniami, stając się podstawą działalności praktycznej w doradztwie nie powinna utracić tego, co decyduje o jej doniosłości jako kulturowego narzędzia oświecenia człowieka. Umożliwia bowiem samoświadome odnoszenie się do świata właśnie dzięki dostarczaniu wielorakich kluczy interpretacyjnych, nie zaś przez udzielanie jednoznacznych odpowiedzi czy konkretnych recept. W doradztwie filozoficznym, o ile będzie ono realizacją powyższych postulatów, możliwe jest zachowanie daleko idącej neutralności, a tym samym umożliwianie wzmacnianie jednostkowej autonomii przez ukazanie szans na samodzielne dokonanie wyboru.

\section{KONTRAKT PROCESU A CELE SPONSORA}

Inny dylemat ujawnia się wokół kwestii kontraktowania usługi; wracając do przedstawionego kazusu, można zauważyć, że gdyby proces był opłacany przez rodzinę, to pełniłaby ona rolę sponsora, który ma pewne oczekiwania, co skutkowałoby pojawieniem się sytuacji analogicznej do tak zwanego trójkąta bermudzkiego w business

28 W odpowiedzi na traktowanie poglądów filozoficznych jako mających li tylko historyczne znaczenie Wojciech Załuski wyraża następującą opinię : „(...) żaden z nich nie zdezaktualizował się w naprawdę istotnym sensie. Uważam, że każdy może być przyjęty przez współczesnego człowieka. I że przyjęcie jednego z tych poglądów jako własnej filozofii życiowej jest lepsze niż życie chaotyczne, to jest nieustrukturyzowane spójnym poglądem na świat i miejsce w nim człowieka. Co więcej uważam, że większość ludzi faktycznie przyjmuje jeden z tych poglądów, choć zazwyczaj (...) bez pełnej świadomości jego historycznych korzeni i wszystkich jego teoretycznych implikacji". W. Załuski, Przeciw rozpaczy. O tragicznej wizji świata i sposobach jej przezwyciężania, Kraków 2014, 14. 
coachingu. W relacji coachingowej w takich wypadkach cele klienta muszą pokrywać się przynajmniej częściowo z celami sponsora ${ }^{29}$. Tu oczekiwania sponsora mogłyby być wyrażone jako oczekiwanie szybkiego powrotu matki-babci do obowiązków oraz wyrwanie jej ze stanu rozpaczy. Czy moralnie słusznym byłoby spełnienie tego typu oczekiwań? Aby doradca mógł się nie wikłać w tego typu wieloznaczne sytuacje, należałoby zatem przedstawić charakter i zasady etyki zawodowej. Pomimo niedookreślenia tej kwestii w Polsce, w innych krajach są już wypracowane standardy tym zakresie, które na razie można traktować nie tylko jako cenną wskazówkę, ale również jako kodeks, którego zasad przestrzeganie deklarujemy umawiając się z klientem. Inną, uzupełniającą propozycją jest przedstawienie klientowi osobistych zasad, które realizuje się jako wynikające $z$ etosu filozofa oraz wartości, którym ma służyć doradztwo filozoficzne, jak np. budowanie samoświadomości, postawa adogmatyczna, odwaga niezależnego myślenia, racjonalizm. A następnie przedstawienie metod pracy, które realizować mają te wartości. Co ułatwia również uświadamianie, jakich celów doradca nie chce realizować lub po prostu nie jest w stanie.

\section{DYLEMAT NA POZIOMIE RELACJI. COACHING A DORADZTWO FILOZOFICZNE}

Na ile dawać klientowi to, czego pragnie, a na ile dbać o obiektywizm i to, co rozwojowo lepsze? Skąd wiemy, że to lepsze? Czy lepszym działaniem jest pogłębienie obiektywizmu, czy lepszym udzielenie jakiejś formy wsparcia? Odpowiedzi na tak postawione pytania wynikają z wyjściowych założeń filozoficznych, które warto na wstępie relacji ujawnić, o czym wspominałam powyżej, a nawet przedyskutować $\mathrm{z}$ klientem. W omawianym kazusie na prośbę

29 M. Sidor-Rządkowska, Profesjonalny coaching. Zasady i dylematy etyczne w pracy coacha, Warszawa 2012, 54-55. 
klientki o rozstrzygnięcie sporu eschatologicznego (dotyczącego życia po śmierci) jako coach mogłabym zapytać: jakie to ma dla Ciebie znaczenie? Co ważnego kryje w sobie odpowiedź na to pytanie? Pytania te, choć pogłębiają rozumienie, zamykają się zasadniczo w subiektywnym doświadczeniu jednostki. Chociaż coaching dysponuje środkami, które pozwalają uwzględniać różne perspektywy, to decydujące jest wspieranie klienta. Już w tym zakresie można znaleźć cechę odróżniającą go od doradztwa filozoficznego. Obie formy pracy są nakierowane wprawdzie na rozwój samoświadomości klienta, jednak podejście coachingowe bliższe będzie akceptacji dla subiektywnego punktu widzenia, nie będzie też dopuszczało wprost kwestionowania poglądów, na przykład $z$ uwagi na racje czysto logiczne. Coach nie może bowiem wyjść z inicjatywą korygowania sposobu myślenia klienta. Debata może być przykładową metoda pracy doradczo-filozoficznej, ujawniającą, że poznawcze korzyści dla rozmówcy wynikają ze ścierania się racji i argumentów, czy zmierzania do uchwycenia istoty rzeczy na drodze stawiania hipotez i próby ich podważania.

Wracając jednak do kwestii żałoby, jako coach nie pracowałabym z osobą w rozpaczy, która nie widzi możliwości zmiany swojej sytuacji, a nawet nie jest skłonna do poszukiwania możliwości zmiany. Cechą dystynktywną doradztwa filozoficznego w stosunku do coachingu, jest po pierwsze możliwość pracy w obszarze pomocowym, a nie tylko rozwojowym. Ponadto zaś umożliwienie klientowi zmierzenia się z egzystencjalnymi pytaniami dla nich samych i przemyślenia ich $\mathrm{w}$ świetle filozoficznego dorobku, ale również z uwzględnieniem indywidualnej, specyficznej sytuacji pytającego. Typ pracy rozwojowej, jaką jest coaching, dedykowany jest właśnie tym osobom, które chcą zmiany, natomiast doradztwo filozoficzne może być skierowane do osób w sytuacji problemowej, bez wyraźnego pragnienia zmiany życiowej, za to przy dużej dozie tęsknoty za zrozumieniem lub odnalezieniem sensu sytuacji. Zorientowanie na taki typ klientów nie jest - co należy podkreślić - wadą coachingu, ale tym, co zapewnia 
mu wysoką skuteczność w pracy nad osiąganiem celów, a bez spełnienia tych warunków byłaby ona również pozbawiona racji. Podejście coachingowe może okazać się wprawdzie wystarczająco zadowalające pod kątem przygotowania narzędziowego $\mathrm{w}$ sytuacji rozstrzygania dylematów moralnych, co tworzyłoby tematycznie część wspólną z doradztwem filozoficznym, ale będzie niewystarczające lub po prostu nieadekwatne w przepracowywaniu np. sytuacji żałoby, czy mierzeniu się z potrzebą merytorycznego przedyskutowania jakiejś opcji światopoglądowej. Pomimo podobieństwa wielu technik, z racji wspólnego dziedzictwa obu podejść, w postaci sokratejskiej dialogiki, zwłaszcza w jej majeutycznej postaci ${ }^{30}$, to tematy i typ sytuacji klientów będą wyznaczać linię demarkacyjną między coachingiem a doradztwem filozoficznym.

Wracając do rozważanego pytania, sądzę, że w jakiejś mierze interesujące jest podejście typowe dla analizy egzystencjalnej, z jej fenomenologicznym zorientowaniem, co oznacza zasadniczo otwartość na wszystko, czego w danej chwili ktoś doświadcza, w tej właśnie postaci, w jakiej zachodzi to dla podmiotu. Celem pracy jest wówczas koncentracja na decyzyjnym potencjale (często nieświadomym) i konfrontowanie go z jego osobistą odpowiedzialnością, gdyż dzięki unaocznieniu emocji obecnych w doświadczeniu, osoba może odkrywać swoją autentyczną pozycję i postawę w stosunku do świata i siebie ${ }^{31}$. W doradztwie filozoficznym ów drugi element - osobistej odpowiedzialności, która odnosi się również do sensów powszechnych - ma szczególne znaczenie w połączeniu z metodami krytycznymi, pozwalającymi na zachowanie dystansu wobec dominujących narracji kulturowych. Przez co pozwala również rozpoznać umowny, konstruowany społecznie charakter psychoterapeutycznych regulacji

30 A. Negri, Dialog Sokratejski w coachingu, w: Coaching jako konstruktywny dialog, red. L. D. Czarkowska, Warszawa 2016, 65-75.

31 A. Längle, Rozmowa terapeutyczna jako droga odkrywania siebie samego. „Drogowskazy” do wolności, art. cyt., 46. 
dotyczących tego, co w zakresie przeżywania, na przykład żałoby, mieści się w normie i jest prawidłowe.

\section{PODSUMOWANIE}

Doradztwo filozoficzne nie jest formą pracy opartej na dyrektywnym udzielaniu rad, czy wskazówek. Nie powinno być postrzegane jako droga dla osób zależnych i biernych, szukających gotowych recept życia. Ma natomiast duży potencjał w zakresie budowania postawy refleksyjności, poszerzania samoświadomości, a przede wszystkim podejmowania istotnych egzystencjalnie kwestii związanych z przeżywaniem sytuacji granicznych. Wnosić można, że specyficzne kompetencje filozoficzne w połączeniu z przygotowaniem do budowania relacji opartej na autentyczności, obecności i empatycznym zrozumieniu, czynią z doradcy filozoficznego odpowiedniego partnera do pracy w obszarach, w których człowiek doświadcza postawienia pod znakiem zapytania, co do samego swego bycia i orientacji życiowej. Kluczowe jest tu odwołanie się do człowieka jako istoty pragnącej zrozumienia i zdolnej do dokonywania różnych wykładni w celu pogłębienia stosunku do samego siebie i świata. Wymaga to uznania za autoteliczne stojących za tym wartości, co niweluje szukanie instrumentalnych, redukcjonistycznych uzasadnień dla zatroskania się człowieka o samego siebie.

\section{BIBLIOGRAFIA}

Cohen J.A., Maunarino A.P., Deblinger E., Terapii traumy traumatycznej żatoby $u d z$ ieci i mtodzieży, tłum. $z$ ang. R. Andruszko, Wydawnictwo Uniwersytetu Jagiellońskiego, Kraków 2011.

Dąbrowski K., Elementy filozofii rozwoju, Polskie Towarzystwo Higieny Psychicznej, Warszawa 1989.

Feltham C., Rodzaje celów, w: Psychoterapia iporadnictwo, red. C. Feltham, I. Horton, t.1, tłum. z ang. J. Bartosik, S. Pykiel, E. Zaremba, P. Bucki, Gdańskie Wydawnictwo Psychologiczne, Sopot 2013, 58-59. 
Femiak T., Terapia filozoficzna, czyli doradztwo filozoficzne w dziataniu, w: Psychoterapia. Pogranicza, red. L. Grzesiuk, H. Suszek, Enteneia, Wydawnictwo Psychologii i Kultury, Warszawa 2012, 461-488.

Frankl V.E., Homo patiens, tłum. z niem. R. Czarnecki, J. Morawski, Instytut Wydawniczy PAX, Warszawa 1984.

Kierkegaard S., Choroba na śmierć, tłum. z duń. J. Iwaszkiewicz, Wydawnictwo Zysk i S-ka, Warszawa 1995.

Längle A., Analiza egzystencjalna - poszukiwanie zgody na życie, Psychoterapia (2003)2(125), 33-46.

Längle A., Rozmowa terapeutyczna jako droga odkrywania siebie samego. „Drogowskazy" do wolności, Psychoterapia (2003)1(124), 41-54.

Mills J., Philosophical Counseling as Psychotherapy: An Eclectic Approach, International Journal of Philosophical Practice, 1(2008), 1-28.

Milner J., O'Byrne P., Poradnictwo krótkoterminowe: narracje i rozwiązania, red. J. Camping, tłum. z ang. M. Trojański, Wydawnictwo Zysk i S-ka, Poznań 2007.

Negri A., Dialog Sokratejski w coachingu, w: Coaching jako konstruktywny dialog, red. L.D. Czarkowska, Wydawnictwo Poltext, Warszawa 2016, 65-75.

Popielisk K., Mamcarz P., Trauma egzystencjalna a wartości, Difin S.A., Warszawa 2015.

Pucko Z., Zrozumieć utratę. Magna quaestio w obliczu żatoby, Wydawnictwo Uniwersytetu Jagiellońskiego, Kraków 2011.

Wójtowicz M., Doświadczenie lęku egzystencjalnego jako sytuacja wyboru, Wydawnictwo Uniwersytetu Śląskiego, Katowice 2005.

Sidor-Rządkowska M., Profesjonalny coaching. Zasady i dylematy etyczne w pracy coacha, Oficyna a Wolters Kluwer business, Warszawa 2012.

Yalom I. D., Patrzac w stońce. Jak przezwyciężyć grozę śmierci, tłum. z ang. A. Dudziak, Warszawa 2008.

Yalom I. D., Psychoterapia egzystencjalna, tłum. z ang. A. Tanalska-Dulęba, Instytut Psychologii Zdrowia. Polskie Towarzystwo Psychologiczne, Warszawa 2008.

Zembrzuska A., Powrót do fllozofii? Rzecz o poradnictwie fllozoficznym, w: Poradnictwo w kulturze indywidualizmu, red. E. Zierkiewicz, V. Drabik-Podgórna, Oficyna Wydawnicza ATUT - Wrocławskie Wydawnictwo Oświatowe, Wrocław 2010, 99-120.

Załuski A.W., Przeciw rozpaczy. O tragicznej wizji siwiata i sposobach jej przezwyciężania, Copernicus Center Press, Kraków 2014.

Żelazny M., Filozofia i psychologia egzystencjalna, Wydawnictwo Naukowe Uniwersytetu im. Mikołaja Kopernika, Torun 2011. 
Żylicz P.O., Praca psychoterapeutyczna z osobami doświadczającymi poczucia winy, w: Psychoterapia. Praktyka, red. L. Grzesiuk, Enteneia, Wydawnictwo Psychologii i Kultury, Warszawa 2006, 507-518.

\title{
MOURNING, DESPAIR, DEATH - A CASE STUDY ANALYSIS. AN ATTEMPT TO DEFINE THE DETAILS OF PHILOSOPHICAL COUNSELING
}

\begin{abstract}
This article examines the principles and methodology of philosophical counseling, including a case study on the experience of mourning. The philosophical approach will be compared and contrasted with psychological therapy, focusing in particular on brief therapy and coaching as forms of therapy oriented towards personal development. The main purpose of this article is to highlight the specific human needs that philosophical counseling can satisfy. The author suggests that philosophical counselling provides values that are not available to the same extent in other forms of therapy discussed in the paper. The analysis presented is also indirectly focused on the skills required to practice philosophical counseling.
\end{abstract}

Keywords: philosophical counseling, psychotherapy, coaching, existentialism, dialogue

\footnotetext{
AGNIESZKA WOSZCZYK

agnieszka.woszczyk@us.edu.pl

Uniwersytet Śląski w Katowicach, Wydział Nauk Społecznych, Instytut Filozofii

Bankowa 11, 40-007 Katowice
}

DOI: 10.21697/spch.2018.54.3.12 